\title{
Design of Resto-barge Garbage and Sanitary Systems
}

\author{
Hari Prastowo ${ }^{1}$, Agoes Santoso ${ }^{2}$, Muhammad Badrus Zaman ${ }^{3}$, Rizqi Ramadhan Pratama ${ }^{4}$
}

(Received: 31 July 2017 / Revised: 01 March 2019 / Accepted: 24 June 2019)

\begin{abstract}
- resto-barge is a barge which converted to floating restaurant, as an answer lacking orders of barge recently. The location is taking in Gili Trawangan, Lombok. The purpose is to design and calculate sewage, sanitary and garbage management systems. Also to calculate bill of material. The sanitary systems have a Taiko UH-2.0 Hydrophore pressure tank. The sewage systems have an Ebara $60 \mathrm{~m}^{3} / \mathrm{h}$ with meter head $15 \mathrm{~m}$. Total cost spent to build those systems is IDR 115.244.500.
\end{abstract}

Keywords — bill of material, resto-barge, sanitary, sewage

\section{INTRODUCTION}

$\mathrm{T}$ ourism has become the largest income in Indonesia.

In 2012, record number of international tourist (tourist traveling abroad) in 2012 reaching 1 billion people with revenue 1.3 trillion US\$ and will increase in the next year. Nevertheless, until 2013 Indonesia has been visited less than $1 \%$ of international tourist, that is 8,6 million international tourists. . Based on the data, it can be concluded that Indonesia must increase the ability to manage tourism and make an innovative tourism which spread in 33 provinces, include Lombok Island in order to compete with other tourist destination in the world.

Lombok is an island in West Nusa Tenggara province. It is roughly $4,514.11 \mathrm{~km} 2$ total area. It also become a tourist magnet besides Bali. In 2015, the number of tourists visiting Gili Trawangan reach 10.000 visitors with tickets sold from Port Bangsal to Gili Trawangan reach the 8200 ticket. [1] Total tourist visits both domestic or international tourists in 2015 reached 503.541 thousand people with an average increase of 1520 percent. With that statistics, Lombok Island specifically Gili Trawangan is one of the popular place to be visited. The idea to convert barge (deck cargo barge) into floating restaurant can be the alternative solution to increase tourist desire.

This research will explain about how to built support system in Restobarge include sanitary, sewage and

Hari Prastowo, Department of Marine Engineering, Institut Teknologi Sepuluh Nopember, Surabaya, 60111, Indonesia. Email: hprastowo@its.ac.id

Agoes Santoso, Department of Marine Engineering, Institut Teknologi Sepuluh Nopember, Surabaya, 60111, Indonesia. Email: agoes@its.ac.id

Muhammad Badrus Zaman, Department of Marine Engineering, Institut Teknologi Sepuluh Nopember, Surabaya, 60111, Indonesia. Email: druz_zaman@ne.its.ac.id

Rizqi Ramadhan Pratama, Department of Marine Engineering, Institut Teknologi Sepuluh Nopember, Surabaya, 60111, Indonesia. Email: ramadhanrizqi14@gmail.com garbage management. In chapter $\mathrm{I}$, it presented a background of this research. In chapter II, it presented literature review of this research. In chapter III, it calculated sanitary, sewage and garbage management. In chapter IV, it will explain about calculating cost of 3 systems. In the end, it will explain conclusion about Restobarge systems and costs.

\section{METHOD}

\section{A. Resto-barge}

Resto-barge is a barge which converted into a floating restaurant, to increase tourist number in Gili Trawangan. It will be located approximately 55 meters from the shoreline of Gili Trawangan. Gili Trawangan is a perfect location because the average height of waves in the area is 0.9 meters with a sea depth is about 6 meters. [2]

\section{B. Sanitary}

Sanitary systems or fresh water systems are fresh water distributes systems in ships which used to fulfill the requirement in ships like drinking, cooking, bathing, laundry etc. In Resto-Barge itself, sanitary system consists of galley, ablutions, wastafel, toilets.

\section{Sewage}

Sewage on sea is generally the waste produced from toilets, urinals and toilets scuppers. The rules say that the sewage can be discharged into the sea water only after it is treated and the distance of the ship is 3 nautical miles from the nearest land (Marpol Annex IV). In RestoBarge, sewage start from scupper, toilets, wastafel, and galley and discharge by small ship.

\section{Garbage Management Plan}

In Resto-Barge, garbage contains every object who have been wasted except dirty water from galley. The garbage is discharge into shore by small ship, because according to Marpol Annex IV the sewage can be discharged into the seawater only after it is treated and the distance of the ship is three nautical miles from the nearest land. 
TABLE 1.

\begin{tabular}{cc} 
& SHIP DATA \\
\hline Ship name & Barge SM 28 \\
\hline LOA & $76.25 \mathrm{~m}$ \\
Breadth & $21.345 \mathrm{~m}$ \\
Depth & $4.88 \mathrm{~m}$ \\
Draft & 3.57 \\
Displacement & 5627 \\
Shipyard & PT. Samudera Marine Indonesia \\
\hline
\end{tabular}

\section{RESULTS AND DISCUSSION}

\section{A. Sewage System Calculation}

In Resto-Barge, sewage system is an important part because the restaurant can occupy 1000 person every day. Therefore, the system should work well to sustain the needs of the Resto-Barge. MARPOL said that the sewage could be discharged into the seawater only after it is treated and the distance of the ship is 3 nautical miles from the nearest land. In Resto-Barge, the sewage system won't use sewage treatment because it's not efficient besides, Resto-Barge is 55 meters from land. Therefore, it's better to used boat with sewage tank to discharge to land. Figure 1 shows the sewage plan for Resto-Barge.

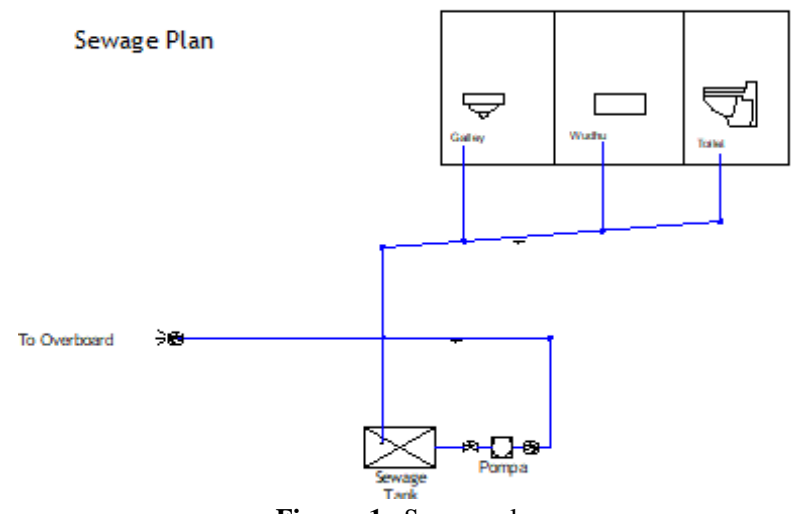

Figure. 1. Sewage plan

To calculate the sewage systems, first to know about sewage tank volume. According to this research data, the volume is $97 \mathrm{~m}^{3}$. After that is moving to velocity of fluid. The step is to determined velocity of fluid $(\mathrm{V})$ and draining time (t) which aim to know about capacity $(\mathrm{Q})$ of pump. To get the value of pump capacity $(\mathrm{Q})$, it can be calculated by formula on equation (1).

$$
\mathrm{Q}=\frac{V}{t}
$$

which $\mathrm{V}$ is $97 \mathrm{~m}^{3}$ and $\mathrm{t}$ is 3 hours. So the capacity is $32.333 \mathrm{~m}^{3} / \mathrm{h}$. The next step after get the capacity is by determine suction and discharge diameter of sewage pipe. PVC Rucika pipe is a model for Resto-barge.

TABLE 2.

PIPE SELECTION

\begin{tabular}{|c|c|c|c|c|}
\hline \multicolumn{2}{|c|}{ Diameter } & \multirow{2}{*}{ Thickness (mm) } & \multirow{2}{*}{ length (m) } & \multirow{2}{*}{ Type of pipe join } \\
\hline inch & $\mathbf{m m}$ & & & \\
\hline $1 / 2$ & 22 & 2.70 & 4 & SP \\
\hline $3 / 4$ & 26 & 2.70 & 4 & SP \\
\hline 1 & 32 & 3.10 & 4 & SP \\
\hline 1. $1 / 4$ & 42 & 3.10 & 4 & SP \\
\hline 1. $1 / 2$ & 48 & 3.60 & 4 & SP \\
\hline 2 & 60 & 4.10 & 4 & SP \\
\hline 2. $1 / 2$ & 76 & 4.10 & 4 & SP \\
\hline 3 & 89 & 5.50 & 4 & SP \\
\hline 4 & 114 & 6.60 & 4 & SP \\
\hline 5 & 140 & 7.00 & 4 & SP \\
\hline 6 & 165 & 8.90 & 4 & SP \\
\hline 8 & 216 & 10.30 & 4 & SP \\
\hline 10 & 267 & 12.70 & 4 & SP \\
\hline 12 & 318 & 15.10 & 4 & SP \\
\hline
\end{tabular}




$\begin{array}{lll}\text { Inside diameter (id) } & =78 \mathrm{~mm} & 0.078 \mathrm{~m} \\ \text { Thickness } & =55 \mathrm{~mm} & 0.0055 \mathrm{~m} \\ \text { Outside diameter (od) } & =89 \mathrm{~mm} & 0.089 \mathrm{~m} \\ \text { Nominal pipe size } & =\text { VP 75 } & \end{array}$

The next step is by calculate head suction. Because there is no head different between velocity and pressure, then it can write as zero (0). Head due to different of height can be write as 1 meter because there is a height difference between suction and pump. To calculate mayor losses, first to do is by calculate Reynolds number $(\mathrm{Rn})$ in equation (2):

$R n=(v x D) / n$

Where $\mathrm{v}$ is the velocity of water, $\mathrm{D}$ is the inside diameter of pipe and $n$ is the viscosity of fluid. After the Reynold number obtained, the next step is calculating coefficient of friction (f) to get mayor losses (hf). To calculate hf it can be seen in equation (3):

$h f=f \times L / D \times v^{2} / 2 g$

where $f$ is the friction on pipe, $L$ is the length of suction pipe, $\mathrm{D}$ is the inside diameter of pipe and $\mathrm{v}$ is velocity of water.

To identify about pipe length and losses like strainer, we should draw sewage pipe in AutoCAD first. In making of sewage pipe from main deck to sewage tank, we must pay attention to slope of the pipe. According to the International Plumbing Code [3-5], sewage pipes should be run with a uniform slope of pipe that it can be seen on table 3 .

According to table 3 , it can be choosing $1 / 8$ " per foot because the sewage pipe is 3 inches or $76.2 \mathrm{~mm}$. Total length of sewage pipe is 118 meters.

TABLE 3.

MINIMUM SLOPE OF PIPE

\begin{tabular}{cc}
\hline Pipe Diameter & Minimum Slope \\
\hline 2 $1 / 2$ " or smaller & $1 / 4$ " per foot \\
3" to 6" & $1 / 8$ " per foot \\
8" or larger & $1 / 16$ " per foot \\
\hline
\end{tabular}

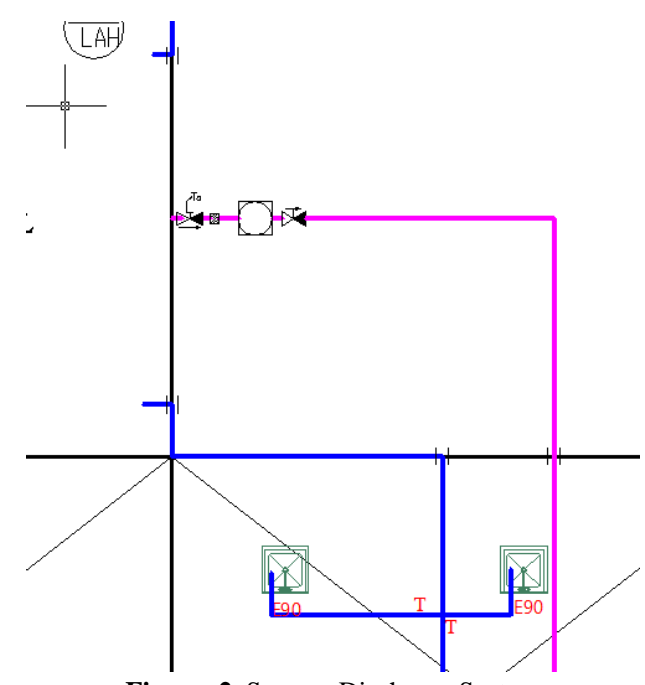

Figure. 2. Sewage Discharge System

TABLE 4.

\begin{tabular}{cccc}
\multicolumn{4}{c}{ THE ACCESSORIES VALUE } \\
\hline Accessories & Quantity (n) & $\mathbf{k}$ & $\mathbf{n ~ x ~ k ~}$ \\
\hline Strainer & 1 & 1.5 & 1.5 \\
SDNRV & 1 & 1.23 & 1.23 \\
& Total & & 2.73 \\
\hline
\end{tabular}

It can be seen from figure 2 that there are two accessories in suction side (the purple line), they are the strainer and the Screw Down Non-Return Valve (SDNRV). The constant value of accessories can be seen on table 4.

After determining the location of minor loses, next step is find the value of Hf. Since HF is very small, it resulted zero (0). The next step calculate the minor loses of sewage system by following the formula in equation (4):

$h l=k \times v^{2} / 2 g$

where $\mathrm{k}$ is the accessories constant, $\mathrm{v}$ is the velocity of water and $\mathrm{hl}$ is $0.01 \mathrm{~m}$ according to equation.

After calculation suction side, the next step is moved to discharge side. In discharge side, the calculation is similar with suction side. The different is in head different of height, where in suction side is 1 meter, in discharge side is 4 meters because the discharge pipe located above main deck, so the height is 4 meters. Another different is in equation (3). The length of pipe is 18 meters according to research. Therefore, the hf is 0.01 meter. Another different is in Constanta in minor losses, when in discharge side is not used strainer. After that, all the formula in discharge side is same with equation (I), (II), (III). After get the answer for all equation, we moved to calculate Total Head (HT) by equation (5):

$H T=H p+H v+H s+H l$ 
Where the $\mathrm{Hp}$ is head difference of pressure, $\mathrm{Hv}$ is head difference of velocity, $\mathrm{Hs}$ is head static and $\mathrm{Hl}$ is head of minor losses.

According to the formula, the answer of HT is 5.04 meters. After get the HT, the next stage is opening manufacturer pump catalogue to find the suitable pump in sewage systems. The most suitable pump specification is presented on table 5 .

TABLE 5.

PUMP SPECIFICATION

\begin{tabular}{cc} 
& PUMP SPECIFICATION \\
\hline Model & Iron Pump Q $4 / 30050 \mathrm{~Hz}$ \\
Capacity & $40 \mathrm{~m}^{3} / \mathrm{h}$ \\
Head & $10 \mathrm{~m}$ \\
RPM & $1000 \mathrm{rpm}$ \\
\hline
\end{tabular}

After get the pump specification, the next step is determining the pipe which cut through the compartment. If there are any, the solution is by welded between pipes and add some flange in the pipe.

\section{B. Sanitary System Calculation}

Sanitary system in Resto-Barge are fresh water distribute systems in ships which used to fulfill the

requirement like cooking and bathing. Fresh water in Resto-barge flow into three parts, galley, toilet, and ablution. Fresh water come from fresh water tank located bellow the deck. To determine the water needs, the author must have calculated from displacement until number of pax. The design of sanitary system known in figure

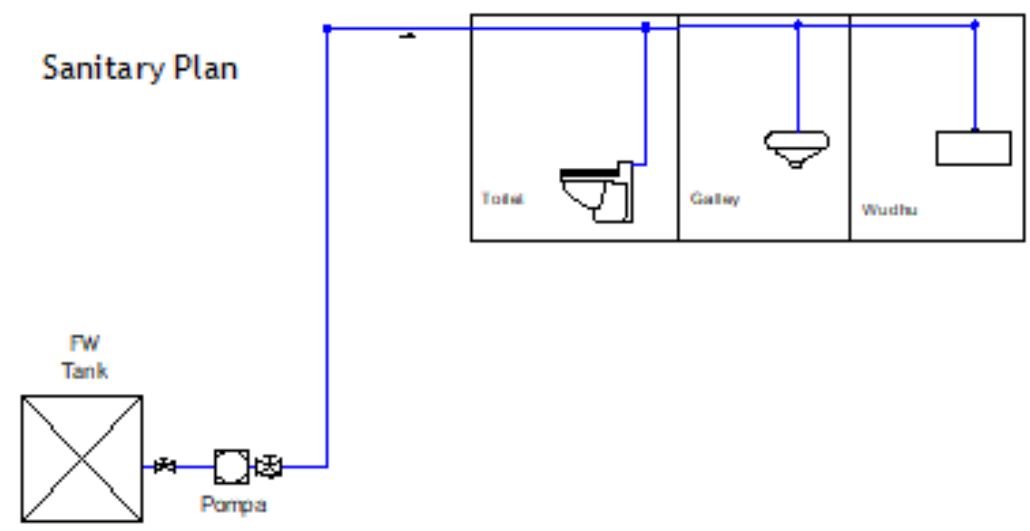

Figure. 3. Sanitary plan

To get the capacity of fresh water, the first to do is known Displacement, LWT, Modified Superstructure, and Outfitting.

Displacement $=(\mathrm{L} \times \mathrm{B} \times \mathrm{T} \times \mathrm{Cb})$

Displacement $=\mathbf{4 9 4 7 . 1 2} \mathrm{ton} / \mathrm{m}^{3}$

Outfitting + Pax + Garbage + Sewage

Total $=\mathbf{2 2 8 9 . 7 4}$ ton

Compartment volume $=1241.576$ ton
LWT $=\mathbf{1 6 2 7}$ ton (previous research data)

Modified Superstructure $=($ Roof + Starboard $\&$ Portside

+ Back \& Front + Divider between Room)

Modified Superstructure $=\mathbf{2 6 1 . 1 3}$ ton

Therefore, to get capacity of fresh water is Displacement - (LWT + Mod. Superstructure + Outfitting

+ Compartment Volume) $=\mathbf{1 4 1 5 . 8 0 4}$ ton

After getting volume of fresh water tank, the author moves to calculate water needs per day shown in table 6 .

TABLE 6

WATER NEEDS PER DAY

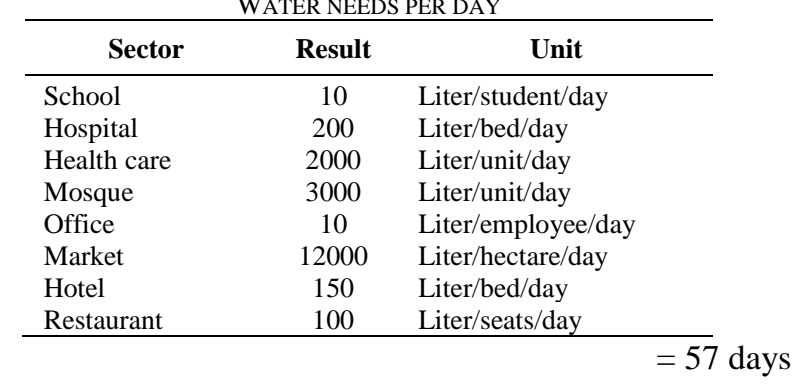

According to table 5, the water need for restaurant is 100 liter/seat/day. If the number of pax is 250 and the desired pax is $1000 /$ day so the water need is 25 ton/day. Fresh Water Tank $=1415.804$ ton

$$
=1415.804 \text { ton } / 25 \text { ton/day }
$$

After that, the next step is moved to calculating capacity of pipe. In Resto-Barge, the calculation can be seen in equation (6):

$Q=$ water needs per day/working hour 
Therefore, water needs per day is $25 \mathrm{~m}^{3}$ and working hour is 8 hours. So the capacity of pipe is $3.125 \mathrm{~m}^{3} /$ hour or $0.00087 \mathrm{~m}^{3} / \mathrm{s}$. After that the next step is determining flow of water between $3-5 \mathrm{~m} / \mathrm{s}$. The author takes the smallest, $3 \mathrm{~m} / \mathrm{s}$. After getting the flow of pipe, the next step is move to calculate standard pipping size in equation (7):

$$
d=\left((4 x Q) /(v x \pi)^{0.5}\right.
$$

The result is $23.5 \mathrm{~mm}$. After get the result, the next step is by comparing the result with the pipe manufacturers catalogue. We used Medium Galvanized Steel Pipe $\varnothing 1.5$ inch with JIS standard as suction pipe, because steel pipe is more durable inside fresh water tank than PVC.

To know the right diameters, the standards pipe must similar with outside diameter of pipe in catalogue. After get the desire result, we also automatically get the thickness and inside diameter with formula outside diameter minus thickness times two.

The result is the inside diameter of pipe is $41.6 \mathrm{~mm}$, the thickness of pipe is $3.5 \mathrm{~mm}$, the outside diameter of pipe is $48.6 \mathrm{~mm}$ and the nominal pipe size is 1.5 .

So the outside diameter of suction pipe made by carbon steel is $41.6 \mathrm{~mm}$ or can used $1.5 \mathrm{inch}$. This also applies with fresh water intake pipe from shore, since the material is same. Because the diameter is difference from earlier, the author can calculate actual flow by equation (8):

$$
v=Q /\left(\pi / 4 x\left((d / 1000)^{2} \times 3600\right)\right)
$$

The result of equation (8) is $1.45 \mathrm{~m} / \mathrm{s}$, or slower because the diameter is bigger than earlier. After get the actual flow, the next step is continuing to discharge pipe. Discharge pipe made by Carbon steel. The line is from discharge until Hydrophore tank. But in fresh water pipe from Hydrophore to unit in main deck, it used PVC pipe, because it can reduce cost. To find the right diameters, the method is same with to find suction pipe. The author used the same diameter as suction pipe and same velocity because the diameter is identical.

After get the actual flow, the next step is continuing to calculating head for suction pump. Because there is no head different between velocity and pressure, then it can write as zero (0). Head due to different of height can be write as 1 meter because there is a height difference between suction pipe and fresh water pump. The next step is continuing to find Reynold's number ( $\mathrm{Rn})$. To find $\mathrm{Rn}$ in sanitary system is same as when we calculate $\mathrm{Rn}$ from sewage system before, by use equation (I). The result is 36423.03. After getting $\mathrm{Rn}$, the next step is continued to find mayor loses (hf). Before calculating hf, the author must find friction coefficient by formula $0.02+0.0005 / \mathrm{d}$. The result is $0.038116 \mathrm{~m}$. Next, the author must find length of pipe by draw in AutoCAD before.

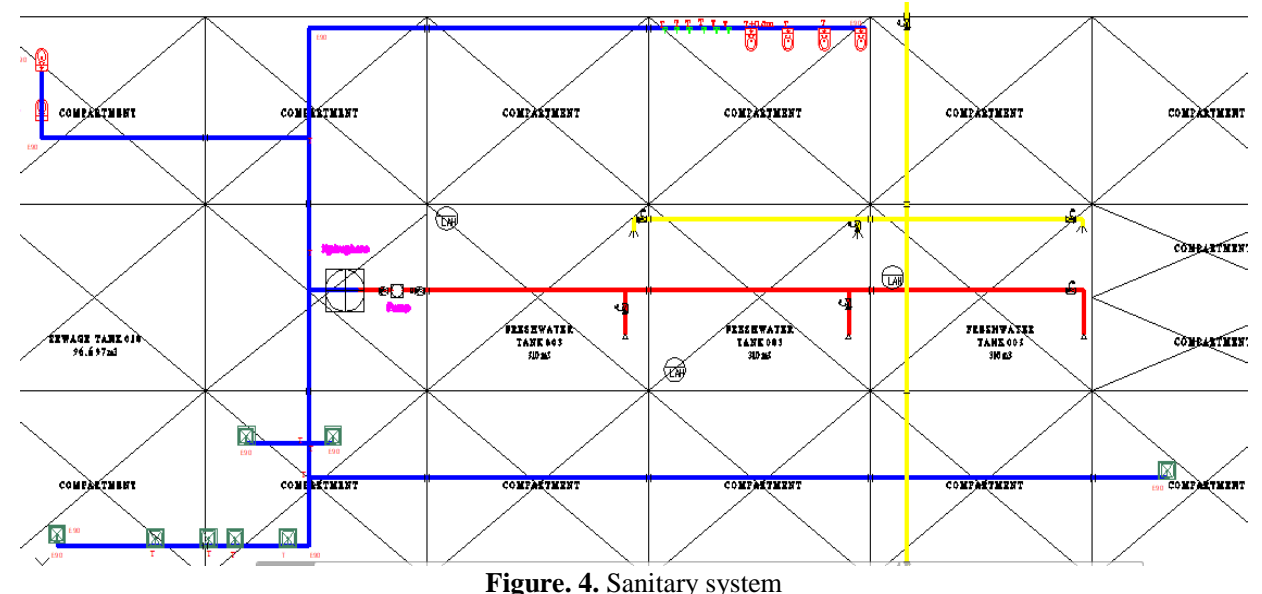

Figure. 4. Sanitary system

According to figure 4, the suction pipe mark with red line when discharge pipe from Hydrophore to unit in main deck mark with blue line and the fresh water intake pipe from land mark with yellow line. Since fresh water intake pipe is same material, length and dimension with suction pipe and the pump is from land, it can be generalized if the mayor losses is almost same with suction pump and not going to calculated. When the discharge pipe from Hydrophore is calculated next. After drawing pipping suction plan, the next step is to placing the minor losses like strainer and non-return valve.
Total length of suction pipe is 33 meters according to AutoCAD drawing. So, after we calculate the equation (3), the mayor losses (hf) is 4.9 meters. Hf is 4.9 meters because the suction pipe is long that makes losses is bigger than the shorter pipe. The next step is calculating minor loses by equation (4). To calculate minor loses there are accessories $(\mathrm{k})$ that have been drawn in figure 5 . The constant value of accessories on figure 5 has been calculate $d$ on table 7. So the result of equation (4) is $1.39 \mathrm{~m}$. 


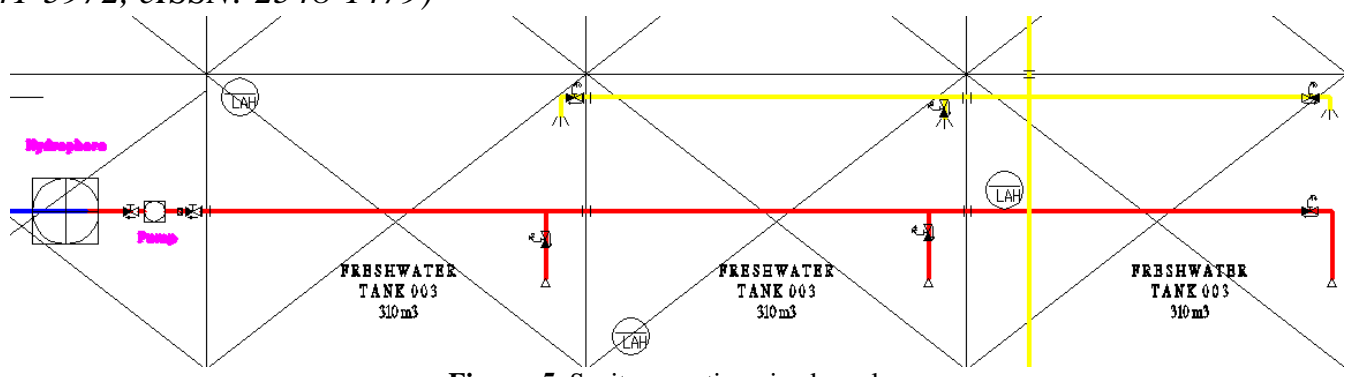

Figure. 5. Sanitary suction pipe key plan

TABLE 7.

THE ACCESSORIES VALUE

\begin{tabular}{llll}
\hline Accessories & Quantity (n) & $\mathbf{k}$ & $\mathbf{n ~ x ~ k ~}$ \\
\hline Strainer & 1 & 1.5 & 1.5 \\
T-Joint & 2 & 2.9 & 5.8 \\
Elbow 90 & 1 & 0.75 & 0.75 \\
SDNRV & $4 \quad 1.23$ & 4.92 \\
& & & 12.97
\end{tabular}

After calculating minor loses in suction side, next is moved to discharge side. In discharge side, the calculation is similar with suction side. The different is in (3) formula. In discharge side, the length of pipe is 2 meters because the discharge pipe is tipped in Hydrophore. So the hf is 0.3 meter, much different than suction side. Another different is in Constanta in minor losses, when in discharge side is only 1 SDNRV. Next, the formula is same with equation (2), (3), and (4). After getting the answer in equation (2), (3), and (4), the next step is moving to Total Head (HT). The formula can be seen in equation (7). According to the formula, the answer of HT is 8.77 meters. Because the capacity and head is obtained, the next step is opening manufacturer pump catalogue to find the suitable pump in sanitary systems. The pump specification for discharge system are shown on table 8

TABLE 8.

\begin{tabular}{cc} 
& TABLE 8. \\
& PUMP SPECIFICATION \\
\hline Model & TMC-32-0.75 \\
Capacity & $5.5 \mathrm{~m}^{3} / \mathrm{h}$ \\
Head & $10 \mathrm{~m}$ \\
RPM & 3600 \\
Power & $0.75 \mathrm{~kW}$ \\
\hline
\end{tabular}

After get the pump specification, the next step is find the Hydrophore Specification. Hydrophore is a tank contain pressured air made by compressor which to maintain the pressure to unit in main deck, as replacement of pump. To calculate Hydrophore Tank, it used equation (9).

$V h=V o+(D x P m) /(t x(P m-P o))$

Where $\mathrm{Vo}$ is the remaining fresh water in tank planning $(2 \% \mathrm{~V}), \mathrm{Pm}$ is the maximum pressure inside tank, planned $5.5 \mathrm{~kg} / \mathrm{m}^{2}$ and $\mathrm{Po}$ is the minimum pressure inside tank, planned $3 \mathrm{~kg} / \mathrm{m}^{2}$

The formula is $\mathrm{Vh}=0.5+(3.125 \times 5.5) /(8 \times(5.5-3)$. So $\mathrm{Vh}=1.6458 \mathrm{~m}^{3}$ or $1600 \mathrm{~L}$. After get $\mathrm{Vh}$, the next step is determining the desired Hydrophore tank by choose the specific data in catalogue of Hydrophore.

Hydrophore which will use in Resto-barge is Taiko UH$2.0-1 \mathrm{R}$.

After get the desired Hydrophore Tank, the next step is by formula $\mathrm{Q}$ of fresh water per day divided operational hours. The result is $8 \mathrm{~m}^{3} / \mathrm{h}$ and head is 20 meters, because total height in Resto-barge is 5 meters, which in diagram below the smallest is 20 meters. Hydrophore pump which will use in Resto-barge is Taiko TMV-32 MT 1.5 Bar.

\section{Garbage Management Plan}

Garbage Management Plan in Resto-barge used a room made by aluminum. It connected to discharge by a 12inch Rucika PVC pipe 4 meter to throw the garbage into small ship.

\section{Material Requirement Planning}

After get the suitable equipment from calculation and design in $\mathrm{A}-\mathrm{B}$, the next step is by doing material requirement planning. It contained data material, amount, and price. Material requirement planning is an important to do because it contained a number of costs which the most important data to investor. The lower of price is the better aspects for investor. In making of Material Requirement Planning, cheaper cost and adequate material is a first choice by author.

For the pricing, the information mostly from PT. Metal Abadi Utama in pipping and small part, PT. Sandai Indah Jaya in pump and Hydrophore and some from website Alibaba. The price possibility is different now because the fluctuated from market. In the table 9 until 11 , there are sanitary systems, sewage systems, and garbage management systems. 
International Journal of Marine Engineering Innovation and Research, Vol. 4(1), Jun. 2019. 11-18

(pISSN: 2541-5972, eISSN: 2548-1479)

TABLE 9.

SANITARY SYSTEM BOM

\begin{tabular}{|c|c|c|c|c|c|}
\hline No & Quantity & Object & $\begin{array}{l}\text { Length } \\
(\mathrm{mm})\end{array}$ & Material & $\begin{array}{l}\text { Price } \\
(\mathbf{R p})\end{array}$ \\
\hline \multicolumn{6}{|c|}{ Intake From Land } \\
\hline 1 & 1 & Main Pipe & 43.464 & Medium Galvanized Steel Pipe sch $40 \varnothing 1.5$ inch & 3.926 .020 \\
\hline 2 & 5 & Screw Down NRV & & Steel Screw Down NRV & 1.000 .000 \\
\hline 3 & 1 & T-Joint & & T Straight S 40 SL & 30.000 \\
\hline 4 & 2 & Elbow $90^{\circ}$ & & Elbow $90^{\circ}$ Seamless SS304L sch 40 & 136.000 \\
\hline 5 & 7 & Flange & & Carbon Steel PN 10 RF STD 1.5 inch & 420.000 \\
\hline \multicolumn{6}{|c|}{ Suction Pipe } \\
\hline 6 & 1 & Main Pipe & 32.000 & Medium Galvanized Steel Pipe sch $40 \varnothing 1.5$ inch & 2.426 .666 \\
\hline 7 & 1 & Screw Down NRV & & Steel Screw Down NRV & 200.000 \\
\hline 8 & 1 & Strainer & & Metal & 400.000 \\
\hline 9 & 2 & T-Joint & & T Straight S 40 SL & 100.000 \\
\hline 10 & 1 & Elbow $90^{\circ}$ & & Elbow $90^{\circ}$ Seamless SS304L & 68.000 \\
\hline 11 & 1 & Pressure Switch & & Coelbo Switchmatic 2 electronic pressure switch & 780.000 \\
\hline 11 & 1 & Level Alarm Ind. & & $\begin{array}{l}\text { Stainless Steel Breaking Water Level Sensor Horizontal } \\
\text { Float Switch }\end{array}$ & 136.000 \\
\hline 12 & 3 & Flange & & Carbon Steel PN 10 RF STD 1.5 inch & 180.000 \\
\hline 13 & 1 & Centrifugal Pump & & Ebara $12 \mathrm{~m} 3 / \mathrm{h}$ head $30 \mathrm{~m}$ & 5.900 .000 \\
\hline \multicolumn{6}{|c|}{ Discharge Pipe } \\
\hline 14 & 1 & Main Pipe & 82.000 & Rucika VP/AW Ø 1.5 inch & 1.845 .000 \\
\hline \multirow[t]{5}{*}{15} & 20 & $\begin{array}{l}\text { Connection Pipe } \\
\text { Between } \\
\text { Compartment }\end{array}$ & 20.000 & Carbon Steel black Spindo ERW sch $40 \varnothing 1.5$ inch & 1.067 .140 \\
\hline & 6 & Closet Washer & & Kloset Wasser WS 88 TS & 900.000 \\
\hline & 6 & Water Closet & & Toto CW660NJ/ SW660J & 12.960 .000 \\
\hline & 8 & $\begin{array}{l}\text { Water } \\
\text { (Kitchen) }\end{array}$ & & AER Kitchen Faucet Table Mounted [ROV 03B] & 1.600 .000 \\
\hline & 6 & Water Tap & & AER Brass Basin Faucet WOV 03B & 1.200 .000 \\
\hline 16 & 10 & Elbow $90^{\circ}$ & & PVC Elbow D Rucika 1.5 inch & 28.000 \\
\hline 17 & 18 & T-Joint & & PVC Tee D Rucika 1.5 inch & 75.600 \\
\hline 18 & 30 & Flange & & PVC Flange & 90.000 \\
\hline \multirow[t]{2}{*}{19} & 1 & Hydrophore & & Taiko UH-2.0 - 1R 8m3/h-head 20m & 14.700 .000 \\
\hline & & Mesure 1ain & & & $\begin{array}{r}\text { Total: } \\
\text { Rp. 48.449.000 }\end{array}$ \\
\hline
\end{tabular}

TABLE 10.

\begin{tabular}{|c|c|c|c|c|c|}
\hline No & Quantity & Object & $\begin{array}{l}\text { Length } \\
\text { (mm) }\end{array}$ & Material & $\begin{array}{l}\text { Price } \\
\text { (Rp) }\end{array}$ \\
\hline \multicolumn{6}{|c|}{ Suction Pipe } \\
\hline 1 & 1 & Main Pipe & 118.00 & Rucika PVC VP/AW Ø 3 inch & 10.068 .350 \\
\hline 2 & 1 & Level Alarm Ind. & & $\begin{array}{l}\text { Stainless Steel Breaking Water Level Sensor } \\
\text { Horizontal Float Switch }\end{array}$ & 136.000 \\
\hline 3 & 14 & T-Joint & & Rucika PVC Tee (D) 3 inch & 242.200 \\
\hline 4 & 15 & Elbow $90^{\circ}$ & & Rucika PVC Elbow $90^{\circ}$ (D) 3 inch & \\
\hline 5 & 1 & $\begin{array}{l}\text { Connection Pipe } \\
\text { Between } \\
\text { Compartment }\end{array}$ & 20.000 & $\begin{array}{l}\text { Medium Galvanized Steel Pipe sch } 40 \varnothing 3 \\
\text { inch }\end{array}$ & 3.400 .000 \\
\hline 6 & 20 & Flange & & Carbon Steel PN 10 RF STD 3 inch & 115.000 \\
\hline \multicolumn{6}{|c|}{ Discharge Pipe } \\
\hline 7 & 1 & Main Pipe & 16.000 & Rucika PVC VP/AW Ø 3 inch & 1.365 .200 \\
\hline 8 & 2 & Screw Down NRV & & Non Return Valve Plastic & 40.000 \\
\hline 9 & 1 & Elbow $90^{\circ}$ & & Rucika PVC Elbow $90^{\circ}$ (D) 3 inch & 35.000 \\
\hline 10 & 3 & Flange & & Carbon Steel PN 10 RF STD 3 inch & 115.000 \\
\hline 11 & 1 & $\begin{array}{l}\text { Connection Pipe } \\
\text { Between } \\
\text { Compartment }\end{array}$ & 6.000 & $\begin{array}{l}\text { Medium Galvanized Steel Pipe sch } 40 \varnothing 3 \\
\text { inch }\end{array}$ & 1.020 .000 \\
\hline $\begin{array}{l}12 \\
13\end{array}$ & 1 & Pump & & Ebara $60 \mathrm{~m} 3 / \mathrm{h}$ head $15 \mathrm{~m}$ & 9.370 .000 \\
\hline
\end{tabular}

Rp. 26.854.416 
Garbage Management:

PVC pipe Rucika 12 inch, IDR 3.241.300

Total Cost of Material: IDR 78.544.500,

Cost of Drawing : IDR 7.000.000,

Cost of Worker :

-IDR 200.000 for foreman (7 hour/day)

-IDR 250.000 for supervisor

-IDR 180.000 for welder (7 hour/day)

-IDR 120.000 for piping worker (7 hour/day)

-IDR 90.000 for worker (7 hour/day)
-IDR 180.000 for two worker

-IDR 140.000 for installator (7 hour/day)

-IDR 360.000 for two Workers

Total cost for worker : IDR 27.000.000,

Cost of Contingencies : $0.5-5 \%$ from total cost. Taken 1\%. : IDR 1.153.000,

Total cost needed to build Sanitary and Garbage Management:

IDR 115.244.500,

TABLE 11.

PROJECT SCHEDULING

\begin{tabular}{lll}
\multicolumn{2}{c}{ PROJECT SCHEDULING } \\
\hline WBS & Task Name & Duration \\
$\mathbf{1}$ & Event & $\mathbf{1}$ \\
1.1 & Contract signing for workers & 1 \\
& & $\mathbf{6}$ \\
$\mathbf{2}$ & Drawing and Cost Estimating & 2 \\
2.1 & Calculation of sanitary and sewage systems & 1 \\
2.2 & Garbage management fixation system & 1 \\
2.3 & Drawing of sanitary system & 1 \\
2.4 & Drawing of sewage system & 1 \\
2.5 & Cost estimating & \\
In this point, & equipment determined and booked (Est 2 days) & \\
& & $\mathbf{1 6}$ \\
$\mathbf{3}$ & Installation & 5 \\
3.1 & Delivery for each equipment & 7 \\
3.2 & Fresh Water pipping system arrangement & 2 \\
3.3 & Sewage pipping arrangement & 1 \\
3.4 & Garbage management arrangement & 1 \\
3.5 & Final Checking and test & $\mathbf{2 3}$ days \\
& Total & \\
\hline
\end{tabular}

\section{CONCLUSION}

Based on the calculation and drawing process, which has been done, to Restobarge sewage, sanitary and garbage management, it can be concluded that:

1. The model of main intake from land and suction pipe in sanitary system is Medium Galvanized Steel Pipe sch $40 \varnothing 1.5$ inch. For discharge pipe to the unit model is Rucika VP/AW Ø $42 \mathrm{~mm}$. The model of Hydrophore Pressure Tank is Taiko UH-2.0 - 1R $8 \mathrm{~m} 3 / \mathrm{h}$-head $20 \mathrm{~m}$.

2. The model of main suction pipe and discharge pipe is Rucika PVC VP/AW Ø 3 inch. The pump of sewage system is Ebara $60 \mathrm{~m} 3 / \mathrm{h}$ head $15 \mathrm{~m}$.

3. Total cost of material of three systems is IDR 78.544.500. The cost of drawing is IDR 7.000.000. The cost of labor, which consist of supervisor, welder, piping officer and worker, is IDR27.000.000, which can be finished in 23 days. Total cost needed to build sanitary and garbage management is IDR 115.244.500.

\section{REFERENCES}

[1] Rasi, "rimanews," 23 December 2015. [Online]. Available:http://rimanews.com/nasional/peristiwa/read/2015 1224/252331/Wisatawan-Serbu-Gili-Trawangan-SemuaHotel-Sudah-Full-Booking-.

[2] D. Y. Akbar, "Technical and Economic Analysis of $250 \mathrm{ft}$ Deck Cargo Barge Conversion Into Restobarge for Gili Trawangan - Ggili Meno Sea, Lombok," Technical and Economic Analysis of 250 ft Deck Cargo Barge Conversion restobarge For Gili Trawangan - Gili Meno Sea, Lombok, pp. 5-6, 2016.

[3] U.P.Code, Guidelines For Septic System Design, California: Iapmo.

[4] Santoso, Agoes; Prananda, Juniarko; Amiadji; Jadmiko, Edi and Murtadha, Izzu Alfaris, "Flat Top Barge 300 feet Using Portable Dynamic Positioning System", International Journal of Marine Engineering Innovation and Research, 2017, Vol. 1, No. 2, ISSN: 2548-1479, page:106-113.

[5] Ariana, I Made; Prastowo, Hari and Paruna, Aldio, "Design of 100 MW LNG Floating Barge Power Plant", International Journal of Marine Engineering Innovation and Research, 2017, Vol. 1, No. 3, ISSN: 2548-1479, page: 120127. 